\title{
Orbital Sarcoma TNM Finding v8
}

National Cancer Institute

\section{Source}

National Cancer Institute. Orbital Sarcoma TNM Finding v8. NCI Thesaurus. Code C140832.

A finding about one or more characteristics of orbital sarcoma, following the rules of the TNM AJCC V8 classification system. This classification does not apply to osseous and cartilag inous tumors arising in bone (are staged according to the classification for bone), secondary tumors that arise in adjacent periorbital sites with orbital invasion (are staged according to the classification for primary site of tumor), lacrimal gland carcinomas (are staged according to the classification for lacrimal gland carcinoma), and lacrimal gland sarcomas (are staged according to the classification for soft tissue sarcoma of the head and neck). There is no proposal for anatomic stage and prognostic groups for orbital sarcomas at this time. (from AJCC 8th Ed.) 